УДК616

\title{
ВАКЦИНАЦИЯ НАСЕЛЕНИЯ. ЗНАЧЕНИЕ ВАКЦИНАЦИИ ДЛЯ ЖИЗНИ ОТДЕЛЬНОГО ЧЕЛОВЕКА И ЧЕЛОВЕЧЕСТВА В ЦЕЛОМ
}

\author{
Агузарова Маргарита Робертовна \\ Гагулаева Кристина Владимировна \\ студенты \\ специальность «Лечебное дело» \\ Научный руководитель: Хутиева Л.М. \\ K.M.H. \\ ФГБОУ ВО СОГМА
}

\begin{abstract}
Аннотация: В современном обществе вакцинопрофилактика стала предметом массовой полемики. Возникают дилеммы о нужности или ненужности вакцинации среди людей. Существует достаточно большое количество людей, выступающих за вакцинацию и также немалое число людей, выступающих против. Данная тема привлекла наше внимание ввиду того, что она является достаточно актуальной в современном мире. Особую актуальность данной проблеме придает то, что сегодня вакцинация является самым эффективным способом борьбы с COVID-19.
\end{abstract}

Ключевые слова: Вакцинация, статистика, преимущества, значение вакцинации, иммунитет.

\section{VACCINATION OF THE POPULATION. THE IMPORTANCE OF VACCINATION FOR THE LIFE OF AN INDIVIDUAL AND HUMANITY AS A WHOLE}

Aguzarova M.R. Gagulaeva K.V. Khutieva L.M.

\begin{abstract}
In modern society, vaccination has become the subject of mass controversy. There are dilemmas about the necessity or uselessness of vaccination
\end{abstract}


among people. There are quite a large number of people who are in favor of vaccination and also a considerable number of people who are against it.

This topic attracted my attention due to the fact that it is quite an urgent issue of the modern world. This problem is particularly relevant because today vaccination is the most effective way to combat COVID - 19.

Key words: Vaccination, statistics, benefits, the value of vaccination, immunity.

Вакцинация (введение вакцины или анатоксина с целью создания активного специфического иммунного ответа иммунной системы организма против возбудителя инфекции) является методом вакцинопрофилактики инфекционных заболеваний и одним из методов иммунизации населения.

Существуют следующие виды иммунитета. Естественный (врожденный) иммунитет - видовая невосприимчивость к определенным возбудителям, приобретенная и генетически закрепленная в процессе эволюции. Наличием видового иммунитета можно объяснить невосприимчивость человека ко многим инфекциям, встречающимся у животных и наоборот. Приобретенный иммунитет формируется в течение жизни. Такой иммунитет всегда специфичен. Он возникает в результате перенесенного заболевания (активный естественный иммунитет) или при иммунизации вакцинами (активный искусственный иммунитет). Пассивный иммунитет возникает в результате введения в организм готовых антител против возбудителя. Пассивный естественный (трансплацентарный) иммунитет возникает в результате передачи готовых антител от матери плоду через плаценту. Пассивный искусственный при введении антисывороток или специфических иммуноглобулинов. Коллективный иммунитет - уровень невосприимчивости всего населения.

Иммунная реакция на введение вакцины развивается в 3 фазы. Эти фазы характерны как для образования антител, так для формирования клеточного иммунитета.

- Первая - латентная фаза (интервал между введением антигена и появлением антител и цитотоксических клеток). Фаза продолжается в течение нескольких суток.

- Фаза роста - накопление антител и иммунокомпетентных клеток в крови, ее продолжительность для разных антигенов составляет от 4 дней до 4-х недель. 
- Фаза снижения иммунитета. Эта фаза происходит сначала быстро, затем медленно в течение нескольких лет или десятилетий. Чем быстрее снижается иммунитет, тем чаще необходимо вводить бустерные дозы вакцины.

Для того, чтобы ответить на вопрос какое значение имеет вакцинация для жизни отдельного человека и человечества в целом рассмотрим историю иммунопрофилактики. Э. Дженнер в XVII веке успешно привил коровью оспу ребенку, предотвратив последующее заражение настоящей оспой. Луи Пастер впервые сформулировал принцип «Если снизить ядовитость микроба, то он превращается в средство защиты от болезни, им вызванной». Он привил курам культуру бацилл сибирской язвы, хранившуюся в неблагоприятных условиях. Куры не заболели, но приобрели устойчивость к сибирской язве. И.И. Мечников в 1881 г. открыл фагоцитоз. Эрлих в 1901 г. сформулировал теорию образования антител. Н.Ф. Гамалеяв 1886 г. создал первую в России бактериологическую станцию и осуществил вакцинацию людей против бешенства. Он предложил метод приготовления противооспенной вакцины, а также по его инициативе в 1818-1819 гг. проведена всеобщая вакцинация против оспы. А.А. Смородинцев разработал и внедрил совместно с Чумаковым М.П. вакцину против полиомиелита, а также создал вакцины против клещевого энцефалита, кори, эпидпаротита. М.П. Чумаков организовал первое в мире производство живой полиомиелитной вакцины. Это сделало Советский Союз первой страной, в которой началась массовая вакцинопрофилактика полиомиелита.

В последние десятилетия отмечены изменения в способах приготовления вакцинных препаратов. На сегодняшний день применяют генетическое конструирование вакцин. Данный подход позволяет исключить из генома бактерий гены, обуславливающие вирулентность, но сохранить гены, ответственные за протективные антигены. Создаются комбинированные вакцины, содержащие адъюванты, способные усиливать иммунный ответ и эффективность вакцинации. На протяжении более чем 215-летней истории вакцинопрофилактика доказала свою эффективность в сохранении жизни людей, а также в уменьшении заболеваемости и смертности населения. Вследствие вакцинации международному сообществу удалось достигнуть глобальной ликвидации оспы, полиомиелита во многих странах мира, провозгласить цель элиминации кори и врожденной краснухи, снизить заболеваемость многими детскими инфекциями. 
По данным ВОЗ, именно вакцинация ежегодно обеспечивает сохранение 7 млн. детских жизней, 800 тысяч детей не становятся инвалидами. Вакцинация ежегодно дарит человечеству 400 млн. дополнительных лет жизни. В какой-то степени человечество обязано вакцинопрофилактике увеличением продолжительности жизни, не отягощённой инфекционными болезнями. Но не смотря на это, развитие вакцинопрофилактики от Э. Дженнера и Л. Пастера до сегодняшнего дня неизменно сопровождалось инцидентами реакций и осложнений у вакцинированных. Именно страх перед поствакцинальными реакциями и осложнениями стал основной причиной антипрививочных настроений. Борцы против прививок пользуются ложной информацией. Именно благодаря мифической природе антипрививочная дезинформация циркулирует в сознании населения вопреки и одновременно с опровергающими её фактами.

Рассмотрим наиболее часто встречающие мифы.

Миф. Вследствие вакцинации возникают побочные эффекты, которые протекают более тяжело и превышают осложнения от соответствующих инфекций.

Факты. Необходимо знать, что вероятность осложнения от вакцинации во много раз меньше, чем вероятность заболеть инфекцией и получить осложнения от болезни.

\begin{tabular}{|c|c|c|c|}
\hline Вакцина & $\begin{array}{l}\text { Поствакцинальные } \\
\text { осложнения }\end{array}$ & Осложнения в ходе заболевания & $\begin{array}{l}\text { Летальность } \\
\text { при } \\
\text { заболевании }\end{array}$ \\
\hline $\begin{array}{l}\text { Ветреная } \\
\text { оспа }\end{array}$ & $\begin{array}{l}\text { Вакцинальный } \\
\text { менинго- } \\
\text { энцефалит - } \\
1 / 500000\end{array}$ & $\begin{array}{l}\text { Менингоэнцефалит - 1/500 } \\
\text { Осложнения ветряной оспы } \\
\text { регистрируются с частотой 5-6\%. } \\
30 \% \text { осложнений - неврологические, } \\
20 \% \text { - пневмонии и бронхиты, } \\
45 \% \text { - местные осложнения, } \\
\text { сопровождающиеся образованием } \\
\text { рубцов на коже. } \\
\text { У 10-20\% переболевших вирус } \\
\text { ветряной оспы пожизненно остается } \\
\text { в нервных ганглиях и в дальнейшем } \\
\text { вызывает другое заболевание, } \\
\text { которое может проявиться в более } \\
\text { старшем возрасте - опоясывающий } \\
\text { лишай или герпес. }\end{array}$ & $0,001 \%$ \\
\hline
\end{tabular}




\begin{tabular}{|c|c|c|c|}
\hline \multicolumn{4}{|c|}{ Продолжение таблицы } \\
\hline \begin{tabular}{|l} 
Корь- \\
паротит- \\
краснуха
\end{tabular} & $\begin{array}{l}\text { Тромбоцитопения } \\
\text { - 1/40 000. } \\
\text { Асептический } \\
\text { (паротитный) } \\
\text { менингит (штамм } \\
\text { Jeryl Lynn) - } \\
\text { менее чем } \\
1 / 100 \text { 000. }\end{array}$ & $\begin{array}{l}\text { Tромбоцитопения - до 1/300. } \\
\text { Асептический (паротитный) } \\
\text { менингит (штамм Jeryl Lynn) - до } \\
1 / 300 . \\
\text { У 20-30\% заболевших паротитом } \\
\text { мальчиков-подростков и взрослых } \\
\text { мужчин воспаляются яички (орхит), у } \\
\text { девушек и женщин в 5\% случаев } \\
\text { вирус эпидемического паротита } \\
\text { поражает яичники (оофорит). Оба } \\
\text { этих осложнения могут стать } \\
\text { причиной бесплодия. } \\
\text { У беременных женщин краснуха } \\
\text { приводит к спонтанным абортам (10- } \\
40 \%), \text { мертворождению (20\%), } \\
\text { гибели новорожденного (10-20\%). }\end{array}$ & $\begin{array}{l}\text { Краснуха } \\
0,01-1 \% . \\
\text { Паротит - } \\
0,5-1,5 \% .\end{array}$ \\
\hline $\begin{array}{l}\text { Коклюш- } \\
\text { дифтерия- } \\
\text { столбняк. }\end{array}$ & $\begin{array}{l}\text { Энцефалопатия- } \\
\text { до1/300 } 000 .\end{array}$ & $\begin{array}{l}\text { Энцефалопатия - до 1/1200. } \\
\text { Дифтерия. Инфекционно- } \\
\text { токсический шок, миокардиты, моно- } \\
\text { и полиневриты, включая поражения } \\
\text { черепных и периферических нервов, } \\
\text { полирадикулоневропатию, } \\
\text { поражения надпочечников, } \\
\text { токсический нефроз - в зависимости } \\
\text { от формы в 20-100\% случаев. } \\
\text { Столбняк. Асфиксия, пневмония, } \\
\text { разрывы мышц, переломы костей, } \\
\text { компрессионные деформации } \\
\text { позвоночника, инфаркт миокарда, } \\
\text { остановка сердца, мышечные } \\
\text { контрактуры и параличи III, VI и VII } \\
\text { пар черепных нервов. } \\
\text { Коклюш. Частота осложнений } \\
\text { болезни: } 1 / 10 \text { - воспаление легких, } \\
\text { 20/1000 - судороги, 4/1000 - } \\
\text { поражение головного мозга } \\
\text { (энцефалопатия). }\end{array}$ & \begin{tabular}{|l} 
Дифтерия - \\
$20 \%$ взрослые, \\
$10 \%$ дети. \\
Столбняк - \\
17 - 25\% (при \\
современных \\
методах \\
лечения), \\
$95 \%-$ \\
у новорож- \\
денных. \\
Коклюш - \\
$0,3 \%$
\end{tabular} \\
\hline
\end{tabular}

На основе данных А.Н. Мац (НИИ вакцин и сывороток им. И.И. Мечникова РАМН). 
Миф. Устраняемые с помощью вакцинации заболевания возможно ликвидированы в той стране, в которой мы проживаем, поэтому вакцинироваться необязательно.

Факты. Число заболеваний, ликвидированных с помощью вакцинации стали гораздо реже встречаться во многих странах, однако вызывающие их возбудители инфекции продолжают циркулировать в некоторых частях света и могут пересекать границы и заражать любого незащищенного человека.

Миф. Вакцинация ослабляет иммунитет человека.

Факты. Вакцины не ослабляют иммунную систему, а напротив укрепляют еe, стимулируя защитные механизмы, которые обеспечивают защиту от развития определенных заболеваний.

Таким образом, можно сделать вывод о том, что вакцинация является выдающимся успехом здравоохранения. Выше описанная история иммунопрофилактики и приведенные факты подтверждают то, насколько радикально вакцинация может решать проблемы борьбы с инфекционными болезнями.

\section{Список литературы}

1. Ковальчук, Л.В. Клиническая иммунология и аллергология с основами общей иммунологии.

2. Ковальчук, Л.В.Ганковская, Р.Я. Мешкова. Клиническая иммунология и аллергология с основами общей иммунологии.

3. Хаитов, Р.М. Иммунология учеб. Для студ. Вузов / Р.М. Хаитов. - 3-е издание.

4. Ярилин А.А. Иммунология.

5. С.Я. Дьячкова. Иммунология.

6. Госманов Р.Г., Колычев Н.М., Равилов Р.Х., Иммунология 